\title{
Overview and Challenges of Chinese Folklore Photography
}

\author{
Ting Zhou ${ }^{1}$ \\ ${ }^{1}$ Fine Art School, Nanjing Normal University, 1st Wen Yuan Road, Nanjing 210046, Jiangsu, China \\ Correspondence: Ting Zhou, Fine Art School, Nanjing Normal University, 1st Wen Yuan Road, Nanjing 210046, \\ Jiangsu, China. E-mail: 11153@njnu.edu.cn
}

Received: April 19, 2016

Accepted: May 10, 2017

Online Published: May 27, 2017

doi:10.5539/ach.v9n2p39

URL: https://doi.org/10.5539/ach.v9n2p39

\begin{abstract}
Folklore is an important component of a national culture. With the advance of human society, old traditions exude more lasting charm. This is not just out of nostalgia but from a national cultural identity. Folklore photography is an image-based visual embodiment of the historical value of folklore and contributes to cultural recording and inheritance. It displays an unparalleled power of expression in all forms of art. In China, a multi-ethnic country with one of the world's greatest ancient civilizations, folklore photography shows rich and varied cultural connotations and forms of expression. This paper first introduces the value and significance of Chinese folklore photography, then reviews the important stages of its development and analyzes the difficulties and challenges therein, and finally looks into the future of Chinese folklore photography.
\end{abstract}

Keywords: folklore photography, folklore culture, form of expression

\section{Value and Significance of Folklore Photography}

\subsection{Witnessing and Recording Cultural Heritages}

China is home to one of the world's greatest ancient civilizations as well as 56 ethnic groups. The national culture is an important part of Chinese culture and is shared by all Chinese people. In the long course of history, all Chinese ethnic groups have created a variety of distinctive and colorful ethnic cultures. After mutual influence and integration, these cultures have enhanced the vitality and creativity of Chinese culture, enriched its connotations and significance, and reinforced the cultural identity and the centripetal force of the Chinese nation. All ethnic groups have made their own contribution to the development and progress of Chinese culture. Every ethnic group has their own customs and shows unique forms in all aspects of food, clothing, shelter and transportation, farming methods, craftsmanship, architectural style, weddings and funerals, religious activities, traditional rituals and celebrations.

China abounds in folklore resources. Ubiquitous and inexhaustible as they are, these folklore resources have important historical value and cultural value. And folklore photography is of great significance to recording history. With the acceleration of the modernization process and the rapid development of science and technology, many folklore phenomena have been gradually replaced by modern ways of life and have eventually faded away(Tao, 2012). It is therefore a top priority to strengthen recording of folklore that manifests as a specific culture. To save the almost extinct folklore cultures, folklore photography plays an irreplaceable role. Compared with written accounts, photographs seem more intuitive and specific in recording, collecting, organizing folklore cultures of all regions and ethnic groups.

The feature of photography determines its irreplaceable role in the preservation of folklore. It is through the use of a rich variety of pictures that it records folklore, all states of life, thereby adding a colorful chapter in the preservation and development of national culture. Folklore photography may build a highly real and visual treasure house of folklore cultures for future generations of the nation. There have been a host of outstanding folklore photographic works that have recorded in detail people's living conditions and their customs and activities. They have considerable folklore and philological value.

\subsection{Excavating and Disseminating Ethnic Cultures}

To some degree, folklore can be regarded as a resource, both culturally and economically. The development of folk resources can take many forms, for example photography which has become an indispensable means in folk resources development thanks to its convenience and ease of operation (Tao, 2012). Folklore photography plays a 
huge role in the communication of national culture. A lot of folklore is initially communicated through photographs and they are known by people as cultural phenomena. Folklore photography also connects Chinese folklore to the world. It is through the links of photography and economy that folklore receives more publicity. The news media, newspapers and magazines provide platforms for photographers to publicize folklore. Folklore photographs feature in many Chinese and international travel publications.

China is an ancient country with history and culture, and has a history of 5000 years. Folk custom, as an important component of culture, is of great significance. Folk photography plays an important role in the excavation and dissemination of folklore. Folklore photography is a universal language shared by people of all races, religions, nations and cultural backgrounds. It facilitates communication, exchange and understanding among different nations, regions and cultures. In today's context of global integration, China must understand the world, and vice versa. In this regard photography can be used as a convenient tool to introduce Chinese folklore to the world, such as dragon-boat racing, Water-Sprinkling Festival, etc. of which media pictures have been well received in the international community, and which constitute great contributions to the dissemination of Chinese culture.

\subsection{Broadening and Enriching the Category of Photography}

The development of digital technology has led to the popularity of photography as a hobby and the emergence of overwhelming photographic works, though production of excellent works seems still a difficult matter. Photographs are easy to be repetitive. The Border Heat, the Religion Rush and other series of topics were once widely welcomed by photographers. Their creation revolved around these limited hot topics and resulted in the "production is easy but creation is difficult" situation. Given different economic conditions and cultural backgrounds, all ethnic groups have developed their unique national psychology, customs, values, religious beliefs, moral customs, lifestyles and codes of conduct. This unique nature of folklore resources determines the richness and diversity of photography themes.

Compared with traditional art, the art of photography has the advantages of easy dissemination, easy preservation, wide application, many ways of expression and high social value. Folklore photography has both broadened the content and enriched the category of photography (Fan, 2010). It isn't equal to documentary photography that records the folklore of ethnic groups using a documentary approach. It's also different from photojournalism. It doesn't entirely fall into the category of art photography since folklore photography doesn't have to focus on light and shadow effects, shooting skills, etc. Rather, folklore photography should be taken as a kind of academic photography in view of the considerable sociological value contained in its cultural connotations and manifestations, so it is worthy of in-depth academic research.

\section{Development Stages of Chinese Folklore Photography}

\subsection{Emergence Stage}

Chinese folklore photography started in the 19th century (Tan, 2004). The earliest folklore photography activities in China were carried by Western photographers. In the mid-19th century, American missionary Reverend Justus Doolittle came to China and preached his religion in its southeastern region. In 1868, he published his collection of works Social Life of the Chinese, recording the country's ritual and religious culture at that time. In the same year, John Thompson traveled to China. He photographed and published Illustrations of China and Its People and other albums, recording women's headdresses, men's long braids and traditional jackets, houses, streets, stalls, vendors, time-honored brands, etc. in the late Qing Dynasty. Cultural and social phenomena in that time were recorded in the form of large format photos from local customs and practices and ancient buildings to religious culture and production activities. Into the beginning of the 20th century, American teacher Luther Knight shot a lot of realistic pictures during his teaching in Sichuan to record his work and life in Sichuan as well as folklore of other places he visited, involving life, farming, commerce and trade and other valuable details (Zhou, 2016). During 1909-1912, French photographer Albert Kahn shot photos of old Beijing quadrangles, the Confucius Temple, Chang'an streets, city gates, shops, wedding celebration and so on, reproducing folk customs and buildings that existed a hundred years ago in China. These photos are not only a portrayal of the history and folklore in the late Qing Dynasty and the early Republic of China, but a witness to the development of Chinese modern history of photography.

\subsection{Formation Stage}

Folklore creation practice by Chinese photographers was stagnant for a long time due to years of war, social turbulence and other objective factors. It wasn't until the 1920s that domestic photographers started to consciously carry out folklore photography activities. Among them Wang Xiaoting (1900-1981), Zhuang Xueben (1909-1984), Sun Mingjing (1911-1992) and Fang Dazeng (1912-1937) produced a large number of photographs that reflect people's social lives and traditional customs (Tan, 2004). 
In 1930s Zhuang Xueben started his tour of Sichuan, Qinghai, Gansu, Yunnan and Inner Mongolia. He surveyed the Tibetan, Yi and Miao minority areas of Xikang (today's western Sichuan and eastern Tibet). Everywhere he went, Zhuang would keep a thorough record of the local ethnic minority's living environment, facial features, costumes and accessories, production conditions and life customs when he would also shoot thousands of photos as evidence. Sun Mingjing's photographs are more all-embracing, including politics, economics, culture and even architecture of the places where he traveled thousands of miles for research purposes. His photographs are also complemented with detailed written records of the content and the backdrop. As a photographer Sun participated in several research expeditions including Trip to the Northwest 1937, Trip to Zigong 1938 and Trip to Sichuan and Xikang 1939. His photos have retained more historical details of the then people's lives for later generations.

Zhuang, Sun et al. were pioneers of Chinese folklore photography who applied the system of photography to the study of society and folklore. They were producers of the earliest photos that have folklore meaning. And these photos they produced have both unique artistic value and high academic value as precious historical data that blazed a trail for folklore photography (Guo, 2013).

\subsection{Development Stage}

After the founding of New China, Chinese folklore photography continued to grow and develop, thanks to the joint efforts of Chinese photographers represented by Lan Zhigui and Western photographers represented by Marc Riboud. In the 1950s, renowned photographer Lan Zhigui went to Tibet for shooting as a journalist and lived there for more than two decades. He witnessed the ups and downs of Tibet's reform. He recorded many historical moments by virtue of his old Rolleiflex and Leica, such as the PLA's entry into Tibet, the construction of Xikang-Tibet Highway (today's Sichuan-Tibet Highway), the democratic reform in Tibet and the establishment of the autonomous region. In 1955, Lan began to use colored film, which made for the earliest color pictures of the history of Tibet. In 1958, his work The Joy of the Festival in Lhasa won the first international gold award in contemporary Chinese photography: Gold Award at the Democratic German International Photography Exhibition. In 1981, Lan Guizhi Tibet Folklore Photography Exhibition was specially held at the 30th anniversary celebration of Southwest Minzu College (present-day Southwest Minzu University), evoking strong responses. Many of the exhibits were included into Tibet No Longer Mediaeval published by Foreign Languages Press. Lan's works are a vivid, visual portrayal of the old, distant stories in Tibet.

Marc Riboud was the first Western photographer admitted to China for shooting in the 1950s. He was later invited to China by Premier Zhou Enlai for many times. More than half a century ago, Marc went to Guangzhou from India via Hong Kong and then went all the way to the north. He recorded what he saw in China along the way, including the landscape of Wuhan and the Yangtze River Bridge which was then under construction. Many black and white snapshots by this famous French photographer have become one of the historical archives of China's radical changes. He had visited China many times since 1957, leaving a great many classic photos. They are about Chinese people's daily life, clothing, architecture and political culture. Marc published The Three Banners of China, Visions of China and other collections of photographs.

In the 1980s, Chinese society entered the transition period of reform and opening up during which folklore photography began to flourish. The rapid development of economic and trade was accompanied by the increasing activity of cultural exchanges. The world's attention was drawn to China's Silk Road culture, national culture, architectural culture and folk arts and crafts (Qi, 2005). In this period, domestic photographers represented by Huang $\mathrm{Fu}$ and $\mathrm{Zhu}$ Jian created a myriad of works reflecting traditional customs and social lives. Huang Fu took up folklore photography practice and research in 1983 . He went deep into the Loess Plateau and shot many pictures of local folk customs. Huang Fu is the founder of the Shaanxi Folklore Photographers Association. He has organized many Loess folklore photography creation activities, Shaanxi folklore photography exhibitions and folklore photography theory seminars, involving professional and amateur photographers from all around Shaanxi and China. He contributed a lot to developing the cause of Shaanxi folklore photography and to excavating and propagating the time-honored Loess folklore culture. In 2009, amid the celebration of the 60th birthday of new China, Huang held a photography exhibition entitled "Ancient Customs of the Loess Plateau" in Atlanta, America, in a drive to introduce the folklore cultures of the Loess Plateau to the other side of the ocean. His contemporary Zhu Jian, also a Shaanxi photographer, began to explore and photograph the folklore of Shaanxi in the 80s. Zhu has deep affection for Shaanxi's folklore culture. Many local customs and practices have a rich traceable history. After all, Shanxxi is one of the birthplaces of the Chinese nation. His photographic works give an accurate record of Shaanxi's conditions and customs. 


\subsection{Progression Stage}

In 1988, "folklore photography" was formally set up as a new category of photography in Contemporary Chinese Movements in Photography in order to commemorate the 150th anniversary of the invention of photography. In 1993, photographer Shen Che founded the China Folklore Photographic Association (CFPA) and served as the President (Yang\&Hu, 2015). The word "folklore photography" has also gradually become an independent term. In 1997, folklore photography was incorporated into the college art education system as an independent discipline. Thus began the stage of its formal operation and steady progress. Fine works of folklore photography continued to spring up.

On December 27, 1998, the Second CFPA National Member Congress was convened in Beijing. On December 30, the CFPA officially launched the first Humanity Photo Awards (HPA). HPA is an international event supported by UNESCO and granted with UNESCO's logo. It is also to date the only international photographic event in the world that has clearly proposed the use of photography as a means to record, disseminate, share and promote diverse cultures (Yang, 2014). Every two years photographers from nearly 100 countries around the world go to this biennial photography contest. UNESCO also takes this opportunity to collect pictures of folklore of more than half of these countries. Over two decades after it was founded, the CFPA now has 50,000 outstanding folklore photographers throughout the country. By use of cameras they set an example of hard work on the rescue and preservation of folklore cultures. Their actions help to increase people's attention to folklore cultures and thus significantly contribute to the preservation of Chinese folklore culture.

\section{Difficulties and Challenges Confronting Chinese Folklore Photography}

\subsection{Complexity of Research Objects}

Chinese ethnic groups are widely distributed. Folklore phenomena vary greatly from region to region, from ethnic group to ethnic group. The vast territory and the wide distribution of all ethnic groups lead to an endless variety of folk traditions and customs. Sometimes two distant places inherit the same folklore phenomenon; sometimes one folklore phenomenon takes two different forms in different places. Even within one ethnic group there will be also subgroups that form quite different life habits under the impact of different natural environments. As a result, every ethnic group shows their distinctive features in costume culture, religious beliefs, life customs and other respects due to regional differences.

There's no doubt that folklore cultures that have been exposed are just the tip of the iceberg. So far folklore photography needs further exploration in both breadth and depth (Mao, 2016). The breadth refers to the overall study of folklore photography activities and the coverage of multi-ethnic folklore cultures. The depth means the content research of folklore photography activities to explain or expose the historical origins of folklore, its social impacts, and psychological reactions of its audience. Folklore photographers mostly dwell in cities and they generally lack the subject knowledge of folklore, not understanding its origin, evolution, inherent laws of development and future trend. Most of them focus on the records of folklore phenomena. In taking photos of ethnic costumes, for instance, photographers are often unable to explain and distinguish the characteristics of costumes as well as regional and ethnic differences on some deep level.

\subsection{Knottiness of Academic Definition}

It has been over 30 years since the concept of folklore photography was born, but its theoretical basis is still relatively weak for want of a complete theoretical system and a solid theoretical foundation as support (Qi, 2005). As an emerging category of photography folklore photography requires theoretical support for its development context, creative laws, aesthetic characteristics and social functions. Some Chinese folklore photographers such as Shen Che et al. have put forward some theories and standards through years of photography practice, but so far systematic conclusions haven't yet been drawn. Academic interpretations of folklore photography are not deep enough when the academic framework is not sound and remains to be built up.

In addition, there isn't a clear definition of folklore photography to distinguish it from other disciplines. In China folklore photography started late, so its impact isn't as far-reaching as other photography categories (Qu, 2009). From the point of view of scientific research, it will be difficult to obtain the true value of a discipline if there aren't thorough, detailed understandings of it. The fact that folklore photograph is an independent discipline highlights its nature, mission, meaning, rules and techniques, and positions it as an interdisciplinary science that's directly or indirectly linked with folklore, anthropology, ethnology, history and photography.

\subsection{Lack of Market Recognition}

At present, millions of stock images fill the market on the one hand, and the Amorous Heat, the Border Heat and the like continue to prevail in folklore photography on the other hand. Folklore photographic works focus on 
spectacular, lively scenes or old, rustic figures, either skimming the surface or expressing feelings through scenes. Most of the works are restricted to the shooting of folklore phenomena without any in-depth study of folklore cultures. They are still at the level of fragmented records, far from being targeted, integrated and systematic. Hence such works cannot resonate with viewers.

One of the challenges confronting folklore photography is a lack of market operation. It is thus necessary to combine folklore photographic development with economic development, for example, to make use of folklore photography resources to promote the development of tourism, or to broaden investment resources. The protection of folklore photography is not only the responsibility of civil society organizations but calls for active support and cooperation of all sectors of the community in all aspects of human resources, material resources, public opinion and so on.

\subsection{Scantiness of Professionals}

Since photography was first introduced into China, folklore photography has grown out of nothing and then into a well-set photographic discipline today. However, its development scale is still limited to small groups of folklore photographers. Chinese folklore photography is beset by a relatively fixed size of disseminators and the audience, a lack of a broad mass base and scantiness of professional folklore photographers (Mao, 2016). Some of the folklore works we see today, such as those by Zhuang Xueben, Lan Zhigui and Huang Fu, are time-tested ones that contain the creator's extraordinary life experiences, keen artistic sense and strong introspective ability. Such works embody the efforts made by folklore photographers of the old generation.

It is a pity that young photographers of the new generation rarely have achievements in folklore photography. And the public only has a superficial understanding of folklore photography and a low interest in experiencing and learning it. Even worse is the fact that traditional culture has become a subject to entertainment and recreation. Folklore photography has a limited space of development. Its levels of theory and practice are both unsatisfying mainly because of the lack of a team of folklore photographers with high quality and creative ability. There are very few excellent folklore photographers and works except the ones mentioned above.

\section{Future of Chinese Folklore Photography}

\subsection{Improving Policy Support}

A nation must have cultural self-awareness in making strides towards modernization. Folklore photography is an amazing blend of beauty, rationality and wisdom of predecessors and descendants. As a part of a nation's cultural and artistic strength, photography, particularly folklore photography, can facilitate social tradition transformation and spiritual civilization development in some way (Sun, 2014). At present, Chinese folklore photography activities need improvement in policy support and organization. China has a vast territory and its ethnic groups are widely distributed. So there's a need for systematic and standardized management of folklore photography activities to achieve the healthy development of folklore photography. To this end, professional organizations need to play a positive role in guiding the work of folklore photography to a more effective and standard direction, so as to avoid any fault line in folklore culture. Specifically, there should be specialized organizations to organize all kinds of folklore photography activities in a planned and step-by-step manner, to support the orderly development of national folklore communication carriers, and to strengthen management and guidance of relevant activities.

If there are no normalized organizations and supportive policies, folklore photography will be "marginalized". To avoid this, the government-dominating mechanism is essential, which means the government assumes the responsibility of protecting and supporting folklore photography. First, the government needs to take strategies and allocate funds to the excavation and research work. It can support the normalization of folklore photography by virtue of libraries and museums for example. Second, the government should attach importance to folklore photography education. Some of the measures can be introducing folklore photography into the college education curriculum system, establishing knowledge and experiment-oriented projects, training specialized personnel, selecting appropriate textbooks, albums and videos data to turn folklore photography into a discipline. Third, the government needs to to carry out social propaganda. Some cultural venues can be taken advantage of to organize folklore photography lectures and appreciation activities, when an incentive mechanism can be established to encourage the orderly development of folklore photography activities.

\subsection{Strengthening Personnel Training}

Folklore photography is a modern approach to recording culture. It is obvious that China is now in dire need of folklore photography personnel since the discipline itself requires strong expertise. On the one hand, it's essential to strengthen the training of high-level folklore photography creation personnel. Data from recent HPAs show a lack of new ideas in China's folklore photographic works, which is very out of tune with its huge team of 
photographers. On the other hand, it's necessary to enhance the training of high-level management personnel. A personnel structural adjustment is urgent in the development of folklore photography. In the face of pressure from global economic and cultural integration, Chinese folklore photography needs to communicate with international folklore photography in order to be geared to international standards. This requires good market insight and control of managers. A high-level manager can shape and lead the entire folklore photographic image market into a healthy direction.

But what should be done to obtain and train folklore photography personnel? The most important thing is that institutions of higher learning need to cultivate qualified, quality personnel in aspects of photography education orientation, curriculum setting, teaching methods and teacher training (Wu, 2016). Then what should be done for high-level management personnel? The strategy can be a combination of cultivation in the industry and introduction from other industries. The introduction of management personnel from other areas or from other countries can effectively promote the industrialization and internationalization of folklore photography.

\subsection{Emphasizing International Exchanges}

Folklore is the most specific and most vivid manifestation of a nation's traditional culture and national spirit (Sun, 2014). A nation can stand as a whole for thousands of years partly because of ties of blood. But most importantly, it is because of the tie of national culture. And folklore culture is an important component and manifestation of this kind of national culture. In the five thousand years of history the Chinese nation has created a splendid national culture, and the folklore of this culture can be well communicated via the artistic form of folklore photography that tells people what things deserve to be called civilized, lofty and progressive. But in a period of its development when feudalism dominated, China closed its doors to international intercourse, making its people both unknowing and unknown. This situation hasn't been much alleviated even today. In the meantime, there is little understanding among the 56 fraternal ethnic groups within the country due to regional factors. More unfortunately, there will be weaker and weaker understanding of traditional culture in the future generations with the development of the society. In this sense, folklore photography can be regarded as a window to the world in light of its national features and visual characteristics. It is a visual means for the world people to understand China and its traditional culture. It is also a visual textbook to deepen understanding among all Chinese ethnic groups, promote national unity, and conduct patriotism education in the young generation (Jiang, 2008).

In addition to China, many other countries in the world boast a rich variety of folklore photographic works, like Spain, Italy, Mexico, India, Laos, Bangladesh and Myanmar (Yang, 2014). Cross-border sharing will be greatly conducive to the exchange between cultures of different countries. Photography events including HPA have effectively accelerated the cross-border exchange and integration of folklore cultures, and promoted the sharing of the world's outstanding folklore photographic works. At the same time, cross-border communication of folklore photography reflects the characteristics of photography activities in different countries and regions, facilitates the communication of folklore photography between different countries, and thereby realizes resource integration and cultural exchange.

\section{Conclusion}

In today's society, folklore photography and its value have been gaining increasing attention. The mission of folklore photography is to rescue intangible cultural heritages and realize their social value. Folklore photography has been playing a positive role in preserving wonderful folklore cultures and boosting the modernization of traditional culture as well as the internationalization of Chinese culture. Folk photographers have been presenting pieces of photographic works full of ethnic cultural connotations using extensive folklore phenomena as a carrier. They have been successfully expressing the unique social significance of folklore works. The best words to summarize the development of folklore photography may be that the road is tortuous, but the future is bright.

\section{Acknowledgements}

This research is supported in part by the Humanities and Social Science Research Program Fund of the Ministry of Education of China (13YJC760120) and the Philosophy and Social Science Foundation of Jiangsu (2012SJB760026)

\section{References}

Tao, S. Y. (2012). Discussion on the essential factors of folk art heritage. National Arts, 2, 91-95. http://dx.doi.org/ 10.16564/j.cnki.1003-2568.2012.02.005

Fan, Z. (2010). Folklore, photography and photographer - on the relationship among the three in the concept of folklore photography. Journal of Nanjing Arts Institute(Fine Arts \& Design, 2, 153-155. 
Tan, Q. Q. (2004). Investigation and research on folklore photography. Journal of China West Normal University Philosophy \& Social Sciences, 5, 94-96. http://dx.doi.org/10.16246/ j.cnki.51-1674/c.2004.05.025

Zhou, T. (2016). Photography inspection on the China Shu culture and folklore of Luther. Art Science and Technology, 1, 37-38.

Guo, S. L. (2013). The study on Zhuang Xue-ben's investigation of the Qiang customs culture. Guizhou Ethnic Studies, 3, 159-162). http://dx.doi.org/10.13965/j.cnki.gzmzyj10026959.2013.03.024

Qi, T. P. (2005). Aesthetic cultural significance and expression methods of folklore photography. Journal of Chizhou University, 2, 55-56. http://dx.doi.org/10.13420/j.cnki.jczu.2005.02.017

Yang, F., \& Hu, B. B. (2015). From scientific tools to subjective emotion - ontology exploration of folklore photography. Art Observation, 10, 109-113.

Yang, Q. P. (2014). Analysing the image value of folklore photography through the winning works of "Human Contribution Award". Journal of Yunnan Normal University.

Mao, Y. Q. (2016). The dilemma and way out of folk photography. Popular literature and Art, 11, 167-169.

Qu, L. (2009). Discussion on the cultural value and manifestation of folklore photography. Journal of Northwest University Philosophy and Social Sciences Edition, 6, 203-206. http://dx.doi.org/10.16152/j.cnki.xdxbsk. 2009.06.022

Sun, Y. Y. (2014). On the shallow excavation of folklore photography. Art Education, 10, 198-199.

Wu, P. K. (2016). Exploration and practice of folklore photography course teaching. Drama House, 11, $234-236$.

Sun, Y. Y. (2014). A probe into the connotation of folk photography. Art Education, 35, 198-199).

Jiang, B. Z. (2008). Folk photography in the view of non-material culture protection. Photographer in China, 32 , 10-11).

\section{Copyrights}

Copyright for this article is retained by the author(s), with first publication rights granted to the journal.

This is an open-access article distributed under the terms and conditions of the Creative Commons Attribution license (http://creativecommons.org/licenses/by/4.0/). 